\title{
STRATEGI PENINGKATAN PENDAPATAN DAERAH MELALUI PEMBERDAYAAN ASET DAERAH DI PROVINSI JAWA TENGAH
}

\author{
STRATEGY FOR INCREASING REGIONAL INCOME THROUGH \\ EMPOWERMENT OF REGIONAL ASSETS IN CENTRAL JAVA PROVINCE
}

\author{
Wiwin Widiastuti, Tri Risandewi \\ Badan Perencanaan Pembangunan, Penelitian dan Pengembangan Daerah \\ Provinsi Jawa Tengah. Jl. Pemuda No. 127 -133, Semarang \\ E-mail: wiwinwidi@gmail.com
}

Diterima: 29 Oktober 2019, Direvisi: 20 Desember 2019, Disetujui: 20 Januari 2020

\begin{abstract}
ABSTRAK
Proporsi penerimaan Pendapatan Asli Daerah (PAD) Provinsi Jawa Tengah masih didominasi pajak daerah, yakni sebesar $83,36 \%$. Sedangkan penerimaan bukan pajak sebesar $16,64 \%$ yang berasal dari lain-lain PAD yang sah $(12,81 \%)$, hasil pengelolaan kekayaan lainnya $(2,94 \%)$ dan retribusi $(0,87 \%)$. Mempertimbangkan pentingnya peningkatan pendapatan daerah Provinsi Jawa Tengah dari sumber non pajak maka perlu dikembangkan penerimaan yang bersumber dari pendapatan lain-lain yang sah seperti pemanfaatan aset daerah. Pada tahun 2015 konstribusi penerimaan lain-lain yang sah dari hasil pemanfaatan aset daerah relatif kecil yaitu kurang dari $1 \%$, sedangkan potensinya dinilai cukup memiliki prospek untuk dapat ditingkatkan. Maka perlu disusun langkah kebijakan guna meningkatkan pemanfaatan aset daerah. Tujuan penelitian ini adalah mengidentifikasi strategi pemberdayaan aset daerah Provinsi Jawa Tengah dan mengidentifikasi peluang alternatif pembiayaan investasi pemberdayaan aset daerah. Penelitian ini merupakan penelitian deskriptif kualitatif dengan teknik pengambilan data menggunakan wawancara mendalam, Focus Group Discussion dan dokumentasi. Hasil penelitian menunjukkan bahwa berdasarkan kondisinya aset Provinsi Jawa Tengah dapat dikelompokkan menjadi aset potensial dan aset kurang potensial. Aset kurang potensial memerlukan perbaikan dalam hal sumber daya manusia; manajemen anggaran; dukungan stakeholder (BPN, dunia usaha, Pemda, Development finance, dll); dan deregulasi. Dalam pemberdayaan aset Provinsi Jawa Tengah diperlukan penyempurnaan manajemen aset, dan penerapan strategi pemberdayaan aset dengan cara: (a).Melibatkan pihak ketiga sehingga dapat mengurangi/menghilangkan biaya pemeliharaan aset dan sekaligus meningkatkan pendapatan daerah; (b). Menjalin kerjasama pengelolaan aset. Dalam penerapan strategi pemberdayaan aset perlu menggunakan instrumen yang obyektif. Kesimpulan diperlukan kemampuan mewirausahakan birokrasi di kalangan pejabat dan pegawai yang mengelola aset-aset daerah, sehingga pengelolaan aset-aset daerah dapat dilakukan secara kreatif dan inovatif, serta mampu beradaptasi dengan perkembangan lingkungan yang dinamis. Untuk meningkatkan pendapatan asli daerah (PAD) dari kontribusi aset daerah, maka perlu dibentuk Tim/Satgas validasi dan pemberdayaan aset.
\end{abstract}

Kata kunci: Pemberdayaan, Aset daerah, Pendapatan asli daerah (PAD), Strategi, Kontribusi

\section{ABSTRACT}

The proportion of revenues from the Central Java Locally-generated Revenue (PAD) is still dominated by local taxes, namely $83.36 \%$. While non-tax revenues of $16.64 \%$ are derived from other legal PAD (12.81\%), other wealth management results $(2.94 \%)$ and retribution $(0.87 \%)$. 
Considering the importance of increasing regional income of Central Java Province from non-tax sources, it is necessary to develop revenues derived from other legitimate income such as utilization of regional assets. From 1\%, while the potential is considered to have enough prospects to be improved. Then it is necessary to formulate policy measures to improve the utilization of regional assets. The aim of the study is to identify strategies for empowering regional assets of Central Java Province and identifying alternative investment financing opportunities for empowering regional assets. Research is a qualitative descriptive study with data collection techniques using in-depth interviews, focus group discussions and documentation. The results of the study show that based on the condition of assets of Central Java Province can be grouped into potential assets and less potential assets. Less potential assets require improvements in human resources, budget management, stakeholder support (BPN, business, local government, development finance, etc.); and deregulation. In empowering the assets of Central Java Province, it is necessary to improve asset management, and the implementation of an asset empowerment strategy by: (a). Involving third parties so as to reduce / eliminate asset maintenance costs and simultaneously increase regional income; (b). Establishing asset management cooperation. In implementing the asset empowerment strategy, it is necessary to use objective instruments. The conclusion requires the ability to entrepreneurial bureaucracy among officials and employees who manage regional assets, so that the management of regional assets can be done creatively and innovatively, and able to adapt to the development of a dynamic environment. To increase local revenue (PAD) from the contribution of regional assets, it is necessary to establish a Team / Task Force for the validation and empowerment of assets.

Keywords: Empowerment, Regional Assets, Locally-Generated Revenue (PAD), Strategy, Contribution

\section{PENDAHULUAN}

Berlakunya

Undang-Undang

Nomor 23 Tahun 2014 tentang Pemerintah Daerah dan Undang-Undang Nomor 33 Tahun 2004 tentang Perimbangan Keuangan antara Pusat dan Daerah di Indonesia telah membawa konsekuensi terjadinya perubahan dalam sistem penyelenggaraan pemerintah di daerah. Kondisi tersebut ditandai dengan semakin banyaknya kewenangan daerah yang dimiliki dan kebijakan pemerintah pusat dalam desentralisasi fiskal yang makin dibatasi. Diharapkan dengan adanya kewenangan tersebut daerah otonom dapat memperoleh sumber pembiayaan dalam melaksanakan otonominya. Untuk itu pemerintah daerah dituntut dapat mengelola kewenangannya dalam meningkatkan Pendapatan Asli Daerah (PAD).

Peran Pemerintah Daerah dalam pelaksanaan pembangunan daerah harus terus ditingkatkan, selaras dengan pembangunan nasional. Hal ini dimaksudkan untuk lebih mewujudkan otonomi daerah yang lebih nyata dan bertanggung jawab. Pembangunan daerah harus dilaksanakan secara terpadu dan serasi oleh Pemerintah Pusat dan Pemerintah Daerah serta secara bersamasama mewujudkan keharmonisan dan keseimbangan pembangunan nasional, serta masyarakat yang adil dan sejahtera.

Salah satu usaha untuk mencapai tujuan tersebut adalah dengan upaya perbaikan dan penyempurnaan dalam bidang keuangan daerah, melalui pelaksanaan Anggaran Pendapatan dan Belanja Daerah (APBD) Provinsi dan Kabupaten/Kota. Dalam sistem keuangan negara yang desentralistik, pajak daerah dan retribusi daerah merupakan komponen penting sumber Pendapatan Asli Daerah (PAD). Bagi pemerintah daerah, besarnya pajak daerah dan retribusi daerah 
menggambarkan kemampuan daerah dalam menggali dan mengadministrasikan sumber-sumber penerimaan pajak dan retribusi yang menjadi kewenangannya. Besarnya pajak dan retribusi daerah sekaligus memberikan gambaran kemandirian fiskal daerah.

Proporsi penerimaan PAD Provinsi Jawa Tengah masih didominasi pajak daerah, yakni sebesar $83,36 \%$. Sedangkan penerimaan bukan pajak sebesar 16,64\% adalah berasal dari lain-lain PAD yang sah $(12,81 \%)$, hasil pengelolaan kekayaan lainnya $(2,94 \%)$ dan retribusi $(0,87 \%)$. Trend penerimaan pajak daerah Provinsi Jawa Tengah selama 3 (tiga) tahun terakhir menunjukkan penurunan yaitu sebesar $111,60 \%$ pada tahun 2013 menjadi $105,04 \%$ pada tahun 2016 dan 86,48\% pada tahun 2015. Berdasarkan fakta tersebut, Pemerintah Provinsi Jawa Tengah sebaiknya mencari alternatif sumber PAD dari penerimaan non pajak.

Dalam 2 tahun terakhir pendapatan Pemerintah Provinsi Jawa Tengah mengalami penurunan dalam pencapaian target. Mempertimbangkan pentingnya peningkatan pendapatan daerah Provinsi Jawa Tengah dari sumber non pajak maka perlu dilakukan dikembangkan penerimaan yang bersumber dari pendapatan lainlain yang sah seperti pemanfaatan aset daerah.

Pada tahun 2017 konstribusi penerimaan lain-lain yang sah dari hasil pemanfaatan aset daerah relatif kecil atau kurang dari $1 \%$, sedangkan potensinya dinilai cukup memiliki prospek untuk dapat ditingkatkan. Sehubungan dengan hal tersebut perlu disusun langkah kebijakan guna meningkatkan pemanfaatan aset daerah.

Penelitian terdahulu mengenai Pengelolaan Aset Daerah Dalam Meningkatkan Sumber Pendapatan Daerah oleh Sanerya Hendrawan (2003), menyatakan bahwa pengelolaan aset daerah secara optimal belum dilaksanakan sehingga menghambat daerah untuk menjadikannya sebagai alternatif sumber pendapatan daerah. Sehingga diperlukan efisiensi dan efektivitas pengelolaan aset daerah dan pemahaman pelaksana tentang bagaimana potensi aset daerah bagi pendapatan daerah.

Penelitian mengenai Peran Manajemen Aset Dalam Pembangunan Daerah, oleh Aras Aira (2014) menyimpulkan bahwa manajemen aset memiliki peran salah satu nya sebagai dasar optimalisasi pendapatan asli daerah (PAD). Dalam pengelolaan aset daerah, pemerintah harus mempertimbangkan perencanaan kebutuhan dan penganggaran, pengadaan, penerimaan, penyimpanan dan penyaluran, penggunaan, penatausahaan, pemanfaatan, pengamanan dan pemeliharaan, penilaian, penghapusan, pemindahtanganan.

Penelitian Strategi Peningkatan PAD Melalui Optimalisasi Pemanfaatan Barang Milik Daerah pada Pemerintah Daerah Provinsi Banten oleh Natta Sanjaya (2018), menyimpulkan bahwa Pemerintah Daerah Provinsi Banten sampai saat ini masih memprioritaskan dan mencari sumber penghasilan dari sektor pajak dan kurang mengoptimalkan sumber retribusi pemanfaatan kekayaan daerah atau Barang Milik Daerah.

Penelitian ini bertujuan untuk memetakan potensi aset daerah dan pemberdayaannya. Manfaat lain dari penyusunan perencanaan penerimaan pendapatan daerah dari sumber pendapatan lain-lain yang sah secara lebih tepat, juga dimaksudkan untuk mengungkap permasalahan-permasalahan berkaitan dengan pengelolaan aset daerah Provinsi Jawa Tengah, menginformasikan potensi aset yang memiliki daya tarik bagi investor serta memberikan alternatif investasi pemberdayaan aset yang dimiliki. 


\section{METODE}

Ruang lingkup dalam penelitian ini adalah untuk memetakan potensi aset daerah Provinsi Jawa Tengah, menganalisis strategi pemberdayaan aset daerah dan mengidentifikasi peluang alternatif pembiayaan investasi pemberdayaan aset daerah. Penelitian dilaksanakan pada akhir tahun 2016. Penelitian merupakan penelitian deskriptif kualitatif dengan teknik pengambilan sampel purposive sampling dan teknik pengumpulan data menggunakan wawancara dengan para pengampu kepentingan aset daerah Provinsi Jawa Tengah, focus group discussion dan dokumentasi.

\section{HASIL DAN PEMBAHASAN}

Inventarisasi Potensi dan Kondisi Aset Daerah di SKPD Provinsi Jawa Tengah yang Layak Diberdayakan Segera.

Lokasi aset Provinsi Jawa Tengah berada di kabupaten/kota se Jawa Tengah, dengan total volume aset sejumlah 999.413. Kapitalisasi nilai aset Provinsi Jawa Tengah sebesar Rp. 23.574.094.674.374. Hasil inventarisasi potensi aset daerah Provinsi Jawa Tengah berdasar neraca aset Pemerintah Provinsi Jawa Tengah hasil audit 31 Desember 2016 sebagaimana data tabel 1 .

Tabel 1.

Inventarisasi Aset Daerah Provinsi Jawa Tengah

\begin{tabular}{clc}
\hline No. & \multicolumn{1}{c}{ Uraian } & Keterangan \\
\hline 1 & Gedung dan bangunan & 4.055 persil \\
2 & Tanah & 9.315 persil \\
3 & Peralatan dan mesin & 441.052 unit \\
4 & Jalan, irigasi dan jaringan & $7.675 \mathrm{Ha}$ \\
5 & Aset tetap lainnya & 537.300 unit \\
6 & Konstruksi dalam pengerjaan & 16 unit \\
\hline
\end{tabular}

Sumber : Neraca Aset Pemprov. Jateng

Berdasarkan kondisi aset Provinsi Jawa Tengah tersebut, aset dapat dikelompokkan menjadi 2, yaitu aset potensial dan aset kurang potensial. Aset potensial merupakan aset yang harus diprospek karena merupakan aset dengan kondisi (a) Prospektif untuk berbagai usaha;(b) Lokasi yang strategis; (c) Dekat dengan pusat kota; (d) Kondisi aset terawat; (e) Trend NJOP meningkat terus; (f) Bebas banjir, tanah longsor, dan lainlain. Sedangan aset kurang potensial adalah aset dengan kondisi (a) Lokasi yang kurang strategis; (b) Kondisi aset rusak atau rusak sebagian; (c) Kurang perawatan; (d) Rawan bencana alam, dan lain-lain.

Dengan kondisi tersebut, maka aset kurang potensial memerlukan perbaikan dalam hal sumber daya manusia; manajemen; anggaran; dukungan stakeholder (BPN, dunia usaha, Pemda, Development finance, dll); dan deregulasi. Sedangkan aset potensial merupakan aset yang memiliki kemungkinan dimanfaatkan secara produktif untuk memberikan sumbangan bagi penerimaan pendapatan asli daerah.

Sedangkan aset potensial merupakan asset yang memiliki kemungkinan dimanfaatkan secara produktif untuk memberikan sumbangan bagi penerimaan pendapatan asli daerah. Aset daerah Provinsi Jawa Tengah dengan kondisi potensial berdasarkan wilayah sebagai berikut: 
Tabel 2.

Inventarisasi Aset Potensial Provinsi Jawa Tengah dan Kondisi Eksisting

\begin{tabular}{|c|c|c|c|c|}
\hline No & Wilayah & Pengelola & $\begin{array}{l}\text { Luas Tanah } \\
\qquad\left(\mathrm{M}^{2}\right)\end{array}$ & Kondisi Eksisting \\
\hline \multirow[t]{2}{*}{1} & Kabupaten & BPAD & 4.200 & Lahan kosong, dipinjam pakai \\
\hline & Karanganyar & & & Polsek Karanganyar $1.000 \mathrm{~m}^{2}$ \\
\hline \multirow[t]{3}{*}{2} & $\begin{array}{l}\text { Kabupaten } \\
\text { Semarang }\end{array}$ & Dinbudpar & $\begin{array}{c}945 \\
2.055\end{array}$ & $\begin{array}{l}\text { Lahan parkir dan kios-kios } \\
\text { pendukung wisata }\end{array}$ \\
\hline & & BPAD & 2.000 & $\begin{array}{l}\text { Lahan pertanian tanpa ijin, lahan } \\
\text { subur, pemandangan alam, ditanami } \\
\text { sayur oleh warga }\end{array}$ \\
\hline & & Disnakkeswan & $\begin{array}{c}7.290 \\
12.562\end{array}$ & Lahan pertanian \\
\hline \multirow[t]{3}{*}{3} & Kabupaten Batang & Dinpertan & 33.400 & $\begin{array}{l}\text { Untuk pemecah batu dan } \\
\text { penimbangan truk muatan tebu }\end{array}$ \\
\hline & & Dinlutkan & 10.360 & Lahan tambak warga tanpa ijin \\
\hline & & BPAD & 15.185 & Untuk pemecah batu \\
\hline \multirow[t]{4}{*}{4} & Kabupaten Demak & Din PSDA & 91.700 & $\begin{array}{l}\text { Strategis di tepi jalan raya Demak } \\
\text { Kudus, lahan kosong, sebagian } \\
\text { didirikan bangunan RM Ayam } \\
\text { Goreng }\end{array}$ \\
\hline & & Din PSDA & 1.314 & $\begin{array}{l}\text { Lahan kosong, } \\
\text { tempat strategis }\end{array}$ \\
\hline & & Din PSDA & 1.021 & Lahan kosong \\
\hline & & Din PSDA & 117.170 & Lahan kosong \\
\hline \multirow[t]{3}{*}{5} & Kota Semarang & Din PSDA & 5.450 & $\begin{array}{l}\text { Strategis di tepi jl. Semarang- } \\
\text { Kendal, lahan kosong }\end{array}$ \\
\hline & & BPAD & 4.286 & Lahan kosong \\
\hline & & BPAD & 20.070 & Lahan kosong \\
\hline \multirow[t]{2}{*}{6} & Kabupaten Pati & BPAD & 2.000 & Lahan kosong, bekas SPBU \\
\hline & & Bakorwil I & 9.490 & $\begin{array}{l}\text { Kosong, Bekas Kantor Samsat / } \\
\text { UP3AD Kab. Pati }\end{array}$ \\
\hline \multirow[t]{2}{*}{7} & Kabupaten Blora & Dinsos & 2.457 & Lahan kosong, semak belukar \\
\hline & & $\begin{array}{l}\text { Din } \quad \text { Bina } \\
\text { Marga }\end{array}$ & $\begin{array}{l}\text { T. } 2.050 \mathrm{~B} . \\
398\end{array}$ & Kosong \\
\hline \multirow[t]{2}{*}{8} & $\begin{array}{l}\text { Kabupaten } \\
\text { Rembang }\end{array}$ & DPPAD & $\begin{array}{l}\text { T. } 2.207 \mathrm{~B} \text {. } \\
234,5\end{array}$ & Kosong \\
\hline & & DPPAD & 5.000 & $\begin{array}{l}\text { Lahan kosong sebagian disewa } \\
\text { pihak ketiga }\end{array}$ \\
\hline \multirow[t]{4}{*}{9} & Kabupaten Kendal & Din. PSDA & 126.270 & Lahan Pertanian \\
\hline & & Din. PSDA & 36.015 & Lahan kosong \\
\hline & & Din. PSDA & 117.166 & Lahan kosong \\
\hline & & Dinlutkan & 22.420 & Tambak warga tanpa ijin \\
\hline \multirow[t]{3}{*}{10} & $\begin{array}{l}\text { Kabupaten } \\
\text { Pemalang }\end{array}$ & Dinbudpar & 16.890 & $\begin{array}{l}\text { Lahan kosong dekat pantai, bekas } \\
\text { rest area }\end{array}$ \\
\hline & & Dinlutkan & 21.110 & $\begin{array}{l}\text { Balai Benih dan Budidaya ikan } \\
\text { payau }\end{array}$ \\
\hline & & Dislutkan & 19.950 & $\begin{array}{l}\text { Balai Benih dan Budaya Ikan Payau, } \\
\text { Kosong }\end{array}$ \\
\hline 11 & Kabupaten Jepara & Dinsos & 43.350 & Lahan kosong, sebagian untuk \\
\hline
\end{tabular}




\begin{tabular}{|c|c|c|c|c|}
\hline No & Wilayah & Pengelola & $\begin{array}{c}\text { Luas Tanah } \\
\left(\mathrm{M}^{2}\right)\end{array}$ & Kondisi Eksisting \\
\hline 12 & Kota Pekalongan & Bakorwil III & 11.050 & $\begin{array}{l}\text { Asrama dan Panti Sosial PKP } \\
\text { waluyotomo Prov. Jateng } \\
\text { Sebagian untuk Kantor Bank Jateng } \\
\text { dan Samsat }\end{array}$ \\
\hline & & Bakorwil III & 33.370 & $\begin{array}{l}\text { Rumah Dinas Bakorwil III, } \\
\text { Bangunan Cagar Budaya }\end{array}$ \\
\hline 13 & Kabupaten Tegal & Diskanlut & 25.000 & $\begin{array}{l}\text { Balai Benih dan Budidaya Ikan Air } \\
\text { Payau }\end{array}$ \\
\hline
\end{tabular}

Sumber: DPPAD Prov. Jateng 2017

Isu strategis dalam kebijakan pengelolaan aset Provinsi Jawa Tengah adalah (a).Kurang tertibnya administrasi manajemen aset; (b) Diperlukannya inventarisasi aset secara fisik dan yuridis; (c) Diperlukannya penilaian aset; (d) Diperlukannya regulasi dan sistem prosedur pola kerjasama aset; (e) Diperlukan keterbukaan informasi OPD; (f) Diperlukan perhatian OPD selaku pengguna aset. Sehingga diperlukan pengelolaan barang milik daerah (BMD) secara optimal, efektif dan efisien.

\section{Strategi Pemberdayaan Aset Daerah}

Memberdayakan aset-aset daerah dapat dimaknai sebagai suatu proses kerja dalam manajemen aset untuk mengoptimalkan potensi fisik, lokasi, nilai, jumlah atau volume, legalitas, dan nilai ekonomi yang dimiliki oleh aset-aset daerah. Ukuran yang seringkali digunakan untuk menilai keberhasilannya antara lain melalui kemampuan aset dalam menjalankan fungsinya untuk melayani para pengguna dan berdasarkan keuntungan finansial yang didapatkan oleh pemilik aset. Keuntungan finansial semakin besar apabila pengelola aset dapat meminimalkan biaya yang harus ditanggung dan memaksimalkan pendapatan yang diperoleh dari aset yang dikelolanya.

Pertimbangan utama yang melandasi perlunya pemberdayaan aset- aset daerah adalah pertimbangan teknis, di samping memperhatikan pula kepentingan daerah dan kepentingan umum. Oleh karena itu, instrumen pemberdayaan aset daerah sepatutnya diawali oleh identifikasi dan inventarisasi nilai dan potensi asetaset daerah. Muara dari aktivitas ini adalah dihasilkannya suatu sistem informasi manajemen aset daerah yang sistematis, holistik, dan komprehensif. Sistem informasi ini perlu dikelola dengan baik dan senatiasa diperbaharui (up date), sehingga akan memudahkan proses pengawasan dan pengendalian pemanfaatan aset-aset daerah. Bilamana diperlukan, sebaiknya dilibatkan pula berbagai profesi atau keahlian yang terkait dengan berbagai aspek manajemen aset, seperti auditor atau penilai profesional.

Dalam pemberdayaan aset Provinsi Jawa Tengah diperlukan penyempurnaan manajemen aset dengan tahapan: (1) Penyempurnaan Inventarisasi aset secara menyeluruh dan detail; (2) Audit legalitas seluruh asset dengan mempriorotaskan asset potensial; (3) Penilaian aset; (4) Optimalisasi aset; (5) Pengembangan Sistem Informasi Manajemen Aset.

Pemberdayaan aset dalam konteks ini dilakukan dengan melibatkan pihak ketiga, yaitu pihak-pihak di luar Pemerintah Provinsi Jawa Tengah, seperti individu masyarakat, yayasan, ataupun swasta. Kerjasama dengan pihak ketiga 
dapat secara langsung mengurangi biaya pemeliharaan aset dan sekaligus meningkatkan pendapatan daerah. Bentukbentuk pemanfaatan aset daerah yang disebutkan di dalam pasal 27 PP No. 27 Tahun 2014 meliputi sewa, pinjam pakai, kerjasama pemanfaatan, bangun guna serah, bangun serah guna, dan kerjasama penyediaan infrastruktur. Masing-masing bentuk pemanfaatan aset daerah memiliki karakteristiknya tersendiri. Selain pemanfaatan, terdapat pula pengaturan untuk pemindahtanganan, penjualan, tukar menukar, hibah, penyertaan modal, pemusnahan, dan penghapusan Barang Milik Daerah (BMD).

Implementasi strategi

pemberdayaan aset daerah tidak dapat dilepaskan dari keberadaan mitra atau pihak lain yang nantinya mengelola aset daerah. Pemilihan mitra pada dasarnya dilakukan dengan memperhatikan prinsipprinsip berupa dilaksanakan secara terbuka, sekurang-kurangnya diikuti oleh 3 peserta, memperoleh manfaat yang optimal bagi daerah, dilaksanakan oleh panitia pemilihan yang memiliki integritas, handal dan kompeten, tertib administrasi, dan tertib pelaporan. Mitra inilah yang secara aktual memberikan manfaat aktual bagi Pemerintah Provinsi Jawa Tengah, karena memiliki tanggung jawab dalam melakukan pembayaran atas pemanfaatan BMD sesuai bentuk pemanfaatan dan menyerahkan hasil pelaksanaan pemanfaatan sesuai ketentuan bentuk pemanfaatan. Di samping itu, mitra juga bertanggung jawab untuk melakukan pengamanan dan pemeliharaan atas BMD yang dilakukan pemanfaatan dan hasil pelaksanaan pemanfaatan BMD, mengembalikan BMD setelah berakhirnya pelaksanaan, serta memenuhi kewajiban lainnya yang ditentukan dalam perjanjian pemanfaatan BMD.

Pemilihan mitra perlu dilakukan secara cermat dan taktis dengan mengikuti semua ketentuan yang telah diatur di dalam Permendagri No. 19 Tahun 2016. Dikatakan cermat, karena pada proses ini terdapat potensi temuan penyimpangan keuangan, baik yang dilakukan dengan sengaja maupun tanpa disengaja. Pemilihan mitra dilakukan melalui tender, sedangkan dalam hal pbyek pemanfaatan berbentuk Kerjasama Pemanfaatan merupakan BMD yang bersifat khusus, maka pemilihan mitra dapat dilakukan melalui Penunjukan Langsung. Adapun taktis bermakna bahwa mitra yang terpilih mampu mengelola aset berupa tanah dan/atau bangunan secara produktif dan memenuhi segenap kewajibannya kepada Pemerintah Provinsi Jawa Tengah.

Dalam pemberdayaan aset perlu penerapan strategi pemberdayaan aset dengan cara: (1) Melibatkan pihak ketiga (individu masyarakat, yayasan, atau swasta), sehingga dapat mengurangi/ menghilangkan biaya pemeliharaan aset dan sekaligus meningkatkan pendapatan daerah; (2) Menjalin kerjasama pengelolaan aset antara lain: sewa, pinjam pakai, kerjasama pemanfaatan, bangun-gunaserah, bangun-serah-guna, kerjasama penyediaan infrastruktur.

Pemberdayaan aset daerah merupakan suatu keharusan bagi Pemerintah Provinsi Jawa Tengah dalam rangka mendukung peningkatan pendapatan daerah. Pemberdayaan aset daerah memerlukan strategi yang tepat dengan memperhatikan ketentuan yang berlaku serta dengan menggunakan instrumen yang obyektif, yaitu: (a) Identifikasi dan inventarisasi nilai dan potensi aset daerah; (b) Adanya sistem informasi manajemen aset daerah; (c) Pengawasan dan pengendalian pemanfaatan aset; (d) Pelibatan berbagai profesi atau keahlian yang terkait, seperti auditor dan penilai. Selain itu, diperlukan kemampuan mewirausahakan birokrasi di kalangan pejabat dan pegawai yang 
mengelola aset-aset daerah, sehingga pengelolaan aset-aset daerah dapat dilakukan secara kreatif dan inovatif, serta mampu beradaptasi dengan perkembangan lingkungan yang dinamis.

Penelitian Strategi Optimalisasi Pengelolaan Aset Daerah untuk Meningkatkan Pendapatan Asli Daerah (Studi pada Badan Pengelola Keuangan dan Aset Daerah Kota Batu) oleh Devi Listya Nurina (2014), menyimpulkan bahwa pengelolaan keuangan daerah tidak hanya mengoptimalkan pada potensi pajak dan retribusi saja, namun dapat dari pengelolaan aset daerah yang efektif dan efisien. Strategi optimalisasi pengelolaan aset daerah serta kontribusi aset daerah terhadap PAD guna melaksanakan tugas penyelenggaraan pemerintahan yang diharapkan dapat meningkatkan PAD.

Menurut Sahid Sutomo, 2013, Pembentukan strategi merupakan hal yang sangat penting dalam kegiatan pengelolaan aset. Seperti yang dikemukakan oleh Bernardz dalam Maharani (2012) bahwa Strategic Asset Management (SAM) adalah suatu model baru untuk mengekstraksi nilai dari aset-aset produksi. Konsep dasar SAM adalah penggunaan sumber daya secara total untuk keunggulan berkompetisi. SAM mencakup prediksi penjualan sampai pada perencanaan produksi, dan berakhir pada serahan produk ke pelanggan. SAM juga meliputi pengelolaan investasi kapital terhadap program peningkatan ROA (Return On Assets) jangka panjang.

\section{Peluang Alternatif Pembiayaan Investasi Pemberdayaan Aset Daerah.}

Alternatif pemberdayaan aset daerah adalah melalui kerjasama dengan pihak ketiga dengan jenis kerjasama (1) pinjam pakai; (2) alternatif pembiayaan lain. Pinjam pakai, yaitu penyerahan Penggunaan barang antara Pemerintah Pusat dan Pemerintah Daerah atau antar
Pemerintah Daerah dalam jangka waktu tertentu tanpa menerima imbalan dan setelah jangka waktu tersebut berakhir diserahkan kembali kepada Pengelola Barang. Kerjasama ini merupakan kerjasama non komersial. Sedangkan alternatif pembiayaan lain, yaitu sewa, kerjasama pemanfatan, guna, bangun guna serah dan kerjasama penyediaan infrastruktur dengan mitra Badan Usaha Swasta, BUMN, BUMD, Koperasi atau Masyarakat.

Maanfaat kerjasama ini adalah untuk (a) peningkatan pendapatan daerah; (b) pemberdayaan aset daerah yang idle; (c) percepatan penyediaan infrastruktur; (d) pemeliharaan aset dilakukan oleh mitra. Kerjasama penyediaan infrastruktur melalui skema Kerjasama Pemerintah dan Badan Usaha (KPBU) dapat dilaksanakan dengan menggunakan availability payment (AP). Skema Kerjasama Pemerintah dan Badan Usaha (KPBU) memungkinkan adanya dukungan pemerintah antara lain melalui bentuk VGF, Availability Payment (AP) dan Penjaminan.

Kebutuhan pembiayaan infrastruktur yang besar dalam pelaksanaan pembangunan daerah, dimungkinkan tidak dapat dibiayai sepenuhnya dari Anggaran Pendapatan Belanja Daerah (APBD). Sumber pembiayaan untuk pembangunan daerah meliputi: Pemerintah Daerah (Pemerintah daerah melalui APBD dan BUMD); Lembaga Pembiayaan (Perbankan dan Institusi Keuangan Non Bank); Badan Usaha/Swasta dan Masyarakat (obligasi)

Alternatif sumber pembiayaan infrastruktur Pemerintah Daerah dapat dibiayai dengan pembentukan BUMD, Pinjaman Bank/Non Bank, Obligasi dan Kerjasama Pemerintah dan Badan Usaha (KPBU) melalui ekuitas dari sponsor dan pinjaman bank/non bank. 
Kerjasama Pemanfaatan Aset Daerah Provinsi Jawa Tengah

Dalam rangka optimalisasi pemanfaatan aset daerah Provinsi Jawa Tengah diperlukan kerjasama dengan berbagai pihak dengan berbagai skenario kerjasama. Penggunaan aset daerah adalah untuk penyelenggaraan/menunjang tugas pokok fungi Organisasi Perangkat Daerah (OPD) dengan ketetapan Gubernur. Sedangkan dalam pemanfaatan aset daerah, pendayagunaan Barang Milik Daerah (BMD) yang tidak digunakan untuk penyelenggaraan tugas pokok fungsi OPD/optimalisasi Barang Milik Daerah (BMD) dengan tidak mengubah status kepemilikan.

Jenis kerjasama pemanfaatan aset daerah Provinsi Jawa Tengah berdasar Peraturan Pemerintah Nomor 27 Tahun 2014 tentang Pengelolaan Barang Milik Negara/Daerah dapat berupa (1) Sewa, yaitu Pemanfaatan Barang Milik Daerah (BMD) oleh pihak lain dalam waktu tertentu dan menerima imbalan uang tunai; (2) Pinjam pakai, yaitu Penyerahan penggunaan barang antara Pemerintah Pusat dan Pemerintah Daerah atau antar Pemerintah Daerah dalam jangka waktu tertentu tanpa menerima imbalan dan setelah jangka waktu tersebut berakhir diserahkan kembali kepada Pengelola Barang; (3) Kerjasama pemanfaatan, yaitu Pendayagunaan Barang Milik Daerah (BMD) oleh pihak lain dalam jangka waktu tertentu dalam rangka peningkatan Penerimaan Negara Bukan Pajak/ pendapatan daerah dan sumber pembiayaan lainnya; (4) Bangun guna serah, yaitu Pemanfaatan barang Milik Daerah (BMD) berupa tanah oleh pihak lain dengan cara mendirikan bangunan dan/atau sarana berikut fasilitasnya, kemudian didayagunakan oleh pihak lain tersebut dalam jangka waktu tertentu yang telah disepakati, untuk selanjutnya diserahkan kembali tanah beserta bangunan dan/atau sarana berikut fasilitasnya setelah berakhirnya jangka waktu; (5) Bangun serah guna, yaitu Pemanfaatan Barang Milik Daerah (BMD) berupa tanah oleh pihak lain dengan cara mendirikan bangunan dan/atau saran berikut fasilitasnya, dan setelah selesai pembangunannya diserahkan untuk didayagunakan oleh pihak lain tersebut dalam jangka waktu tertentu yang disepakati; (6) Penyediaan Infrastruktur, yaitu Kerjasama antara Pemerintah dan Badan Usaha untuk kegiatan penyediaan infrastruktur sesuai ketentuan Perundangundangan. Dengan semikian diperlukan peran aktif masyarakat, investor, BUMN, BUMD dan Lembaga Keuangan

Alternatif jenis pemanfaatan aset daerah Provinsi Jawa Tengah yang potensial sebagai berbagai jenis tempat usaha, diantaranya: SPBU; Hotel/villa/penginapan; Rumah makan/restoran; Perkebunan; Pertanian; Minimarket; Toko/rumah toko; Area parkir; BPR/BKK; Pergudangan; Rest area; Pasar tradisional; Rusunawa, dan lain-lain sebagaimana tabel berikut: 
Tabel 3.

Aset Potensial Provinsi Jawa Tengah dan Prospek Pemanfaatannya

\begin{tabular}{|c|c|c|c|c|}
\hline No & Wilayah & Pengelola & $\begin{array}{l}\text { Luas Tanah } \\
\left(\mathrm{M}^{2}\right)\end{array}$ & Prospek Pemanfaatan \\
\hline 1 & $\begin{array}{l}\text { Kabupaten } \\
\text { Karanganyar }\end{array}$ & BPAD & 4.200 & $\begin{array}{ll}\text { Minimarket/ } & \text { restoran/ } \\
\text { pergudangan/ parkir dll } & \end{array}$ \\
\hline \multirow[t]{3}{*}{2} & Kabupaten Semarang & Dinbudpar & $\begin{array}{l}945 \\
2.055\end{array}$ & Pengembangan objek wisata alam \\
\hline & & BPAD & 2.000 & $\begin{array}{l}\text { Hotel/wisata alam/ pembibitan } \\
\text { tanaman pangan }\end{array}$ \\
\hline & & Disnakkeswan & $\begin{array}{l}7.290 \\
12.562\end{array}$ & $\begin{array}{l}\text { Rumah Makan/ } \\
\text { pemancingan/wisata alam }\end{array}$ \\
\hline 3 & Kabupaten Batang & $\begin{array}{l}\text { Dinpertan } \\
\text { Dinlutkan } \\
\text { BPAD }\end{array}$ & $\begin{array}{l}33.400 \\
10.360 \\
15.185\end{array}$ & $\begin{array}{l}\text { SPBU/ Gudang/ Rumah Makan } \\
\text { Pembibitan ikan/ Tambak } \\
\text { SPBU/ Gudang/ Rumah Makan }\end{array}$ \\
\hline \multirow[t]{4}{*}{4} & Kabupaten Demak & Din PSDA & 91.700 & $\begin{array}{l}\text { SPBU/Gudang/Rumah } \\
\text { makan/Pengembangan aneka } \\
\text { usaha }\end{array}$ \\
\hline & & Din PSDA & 1.314 & Restoran dan usaha lain \\
\hline & & Din PSDA & 1.021 & Ruah makan/ Gudang \\
\hline & & Din PSDA & 117.170 & $\begin{array}{l}\text { SPBU/ Gudang/ Rumah Makan/ } \\
\text { Rest Area }\end{array}$ \\
\hline \multirow[t]{2}{*}{5} & Kota Semarang & $\begin{array}{l}\text { Din PSDA } \\
\text { BPAD }\end{array}$ & $\begin{array}{l}5.450 \\
4.286\end{array}$ & $\begin{array}{l}\text { SPBU/ Rumah makan/ usaha lain } \\
\text { Pergudangan }\end{array}$ \\
\hline & & BPAD & 20.070 & $\begin{array}{l}\text { Tambak/ Rumah Makan/ } \\
\text { Pemancingan }\end{array}$ \\
\hline \multirow[t]{2}{*}{6} & Kabupaten Pati & BPAD & 2.000 & SPBU/ Rumah Makan/ Gudang \\
\hline & & Bakorwil I & 9.490 & $\begin{array}{l}\text { Perkantoran/Hotel/ } \\
\text { makan/ usaha lainnya }\end{array}$ \\
\hline \multirow[t]{2}{*}{7} & Kabupaten Blora & Dinsos & 2.457 & Pengembangan usaha \\
\hline & & $\begin{array}{l}\text { Dinas Bina } \\
\text { Marga }\end{array}$ & $\begin{array}{l}\text { T. } 2.050 \mathrm{~B} . \\
398\end{array}$ & Rumah makan, gudang \\
\hline \multirow[t]{2}{*}{8} & Kabupaten Rembang & DPPAD & $\begin{array}{l}\text { T. } 2.207 \mathrm{~B} \text {. } \\
234,5\end{array}$ & Hotel/ Rumah makan/Kios-kios \\
\hline & & DPPAD & 5.000 & Kios/ homestay/Pasar tradisional \\
\hline \multirow[t]{3}{*}{9} & Kabupaten Kendal & $\begin{array}{l}\text { Din. PSDA } \\
\text { Din. PSDA }\end{array}$ & $\begin{array}{l}126.270 \\
36.015\end{array}$ & $\begin{array}{l}\text { Perkebunan/ Pertanian/ Hotel } \\
\text { Perkebunan/ Pertanian }\end{array}$ \\
\hline & & Din. PSDA & 117.166 & $\begin{array}{l}\text { Perkebunan/ Pertanian/ } \\
\text { Pergudangan }\end{array}$ \\
\hline & & Dinlutkan & 22.420 & Pembibitan ikan/ Tambak \\
\hline 10 & Kabupaten Pemalang & $\begin{array}{l}\text { Dinbudpar } \\
\text { Dinlutkan } \\
\text { Dislutkan }\end{array}$ & $\begin{array}{l}16.890 \\
21.110 \\
19.950\end{array}$ & $\begin{array}{l}\text { Rest area/ obyek wisata pantai } \\
\text { Budidaya ikan /pertambakan } \\
\text { Budidaya ikan /pertambakan }\end{array}$ \\
\hline 11 & Kabupaten Jepara & Dinsos & 43.350 & $\begin{array}{l}\text { Rumah Makan/ Pembibitan ikan/ } \\
\text { Tambak }\end{array}$ \\
\hline \multirow[t]{2}{*}{12} & Kota Pekalongan & Bakorwil III & 11.050 & $\begin{array}{l}\text { Perkantoran/Rumah } \\
\text { Pameran Produk Lokal }\end{array}$ \\
\hline & & Bakorwil III & 33.370 & $\begin{array}{l}\text { Hotel/ Rumah makan / tempat } \\
\text { promosi aneka produk }\end{array}$ \\
\hline 13 & Kabupaten Tegal & Diskanlut & 25.000 & Budidaya Ikan/ Pertambakan \\
\hline
\end{tabular}

Sumber: Data primer yang diolah 2016 


\section{Manajemen Pengelolaan Aset Daerah}

Teori Pengelolaan Aset Daerah (Yusuf, 2013) menyatakan siklus pengelolaan aset adalah tahapan-tahapan yang harus dilalui dalam manajemen aset. Dalam Permendagri Nomor 19 Tahun 2016 disebutkan bahwa yang dimaksud dengan Pengelolaan Barang Daerah adalah suatu rangkaian kegiatan dan tindakan terhadap daerah yang meliputi: (1) Perencanaan Kebutuhan dan Penganggaran; (2) Pengadaan; (3) Penggunaan; (4) Pemanfaatan; (5) Pengamanan dan Pemeliharaan; (6) Penilaian; (7) Pemindahtanganan; (8) Pemusnahan; (9) Penghapusan; (10) Penatausahaan dan Pembinaan dan (10) Pengawasan dan Pengendalian.

Hasil penelitian Peningkatan Kinerja Manajemen Pengendalian Aset Tetap Kabupaten Purbalingga oleh Faqikh Andri Rokhmadi (2018) menyimpulkan bahwa Pejabat pengelola aset perlu meningkatkan pengawasan, monitoring dan evaluasi terhadap kegiatan pengelolaan aset, mulai dari tahap perencanaan, pengadaan sampai tahap penghapusan aset. Sedangkan hasil penelitian Strategi Optimalisasi Aset Idle Daerah Provinsi Jawa Tengah oleh Shara Meilyanti Anartany \& Deky Aji Suseno (2018), menyimpulkan bahwa: (1) faktor sewa dan sumber daya manusia menjadi penyebab aset daerah menjadi aset idle. Faktor sewa disebabkan karena tarif sewa yang ditentukan berdasarkan lokasi aset. Dan faktor sumber daya manusia disebabkan karena kualitas sumber daya manusia yang dimiliki untuk mengelola aset tidak sesuai; dan (2) Strategi optimalisasi aset idle daerah untuk meningkatkan pendapatan asli daerah yang pertama yaitu dengan menentukan tarif sewa berdasarkan kondisi dan lokasi aset. Yang kedua dengan menambah sumber daya manusia dan meningkatkan kualitas sumber daya manusia dalam pengelolaan aset. Disarankan untuk bisa: (1)
Menyewakan aset kepada pihak lain agar bisa menambah pendapatan dengan tarif sewa berdasarkan kondisi aset sebagai dasar penetuannya. (2) Meningkatkan kualitas sumber daya manusia dalam pengelolaan aset dengan mengadakan pelatihan rutin bagi pengelola aset daerah. Tujuannya agar aset yang dikelola bisa dioptimalkan dengan baik

Pelaksana manajemen pengelolaan aset di Jawa Tengah adalah Badan Pengelola Keuangan dan Aset Daerah (BPKAD) Provinsi Jawa Tengah, yang diampu oleh 1 (satu) bidang eselon III, yaitu Bidang Aset Daerah dibantu 3 (tiga) eselon IV, yakni Sub Bidang Perencanaan Pengadaan dan Pemanfaatan Aset Daerah, Sub Bidang Penatausahaan Barang daerah dan Status Penguasaan Aset Daerah dan Sub Bidang Perubahan Status hukum dan Pengamanan Aset Daerah. Selain BPKAD, aset daerah Pemerintah Provinsi Jawa Tengah juga terdapat di bawah penguasaan Organisaasi Perangkat Daerah (OPD) yang setiap tahunnya memerlukan biaya pemeliharaan yang kadang tidak sebanding dengan hasil pendapatannya. Sehingga diperlukan optimalisi pengelolaan aset daerah sertaefektivitas dan efisiensi dalam pengelolaan manajemen aset daerah secara professional.

\section{KESIMPULAN}

Untuk mengoptimalisasikan aset daerah Provinsi Jawa Tengah, perlu segera dilaksanakan program penggunaan pemanfaatan dan pengamanan aset melalui kegiatan (a) Pembentukan Tim Koordinasi Pemanfaatan Aset Daerah Pemerintah Provinsi Jawa Tengah; (b) Inventarisasi aset yang sudah tidak optimal; (c) Kegiatan kajian untuk mendapatkan landasan rasional dan obyektif terhadap pencapaian kinerja pemberdayaan aset; (d) Pembentukan satgas inventarisasi/validasi aset data; (e) 
Pembentukan satgas pemberdayaan/ revitalisasi aset daerah; (f) Monitoring dan Evaluasi. Untuk meningkatnya pendapatan asli daerah (PAD) dari kontribusi aset daerah, maka perlu dibentuk Tim/Satgas validasi dan pemberdayaan aset daerah.

\section{UCAPAN TERIMA KASIH}

Ucapan terima kasih disampaikan kepada Kepala Badan Penelitian dan Pengembangan Provinsi Jawa Tengah, Kepala Dinas Pendapatan dan Aset Daerah serta staf yang telah membantu terlaksananya penelitian ini 


\section{DAFTAR PUSTAKA}

Jurnal:

Aira, Aras 2014, Peran Manajemen Aset Dalam Pembangunan Daerah, Jurnal Penelitian Social Keagamaan, Vol.17

Nurina, Devi Listya 2014. Strategi Optimalisasi Pengelolaan Aset Daerah untuk Meningkatkan Pendapatan Asli Daerah (Studi pada Badan Pengelola Keuangan dan Aset Daerah Kota Batu). Jurnal Administrasi Publik. Volume 2 Nomor 11

Rokhmadi, Faqikh Andri, 2018, Peningkatan Kinerja Manajemen Pengendalian Aset Tetap Kabupaten Purbalingga. Jurnal Manajemen Pembangunan Daerah. Volume 10 Nomor 1.

Jumanah, Natta Sanjaya, 2018, Strategi Peningkatan PAD Melalui Optimalisasi Pemanfaatan Barang Milik Daerah pada Pemerintah Daerah Provinsi Banten, Journal of Indonesian Public Administration and Governance Studies (JIPAGS)

Anartany, Shara Meilyanti \& Deky Aji Suseno, 2018, Strategi Optimalisasi Aset Idle Daerah Provinsi Jawa Tengah, Economics Development Analysis Journal 7 (1) (2018)

\section{Buku}

Hendrawan, Sanerya et all, 2003. Model Pengelolaan Aset Daerah Dalam Meningkatkan Sumber Pendapatan Daerah (Kajian Bisnis), Bandung: Lembaga Penelitian Universitas Parahyangan

Yusuf, M. 2013, 8 Langkah Pengelolaan Aset Daerah, Jakarta: Salemba Empat

\section{Skripsi/Tugas Akhir:}

Maharani, Rahmadita. 2012. Strategi Perancangan Optimasi Pemanfaatan Aset Lahan Dan Bangunan Kantor Unit Pemasaran III Cabang Bandung PT Pertamina (Persero). Bandung: Politeknik Negeri Bandung

Peraturan Perundangan-undangan:

Pemerintah Republik Indonesia, 2016. Peraturan Menteri Dalam Negeri Republik Indonesia Nomor 19 Tahun 2016 Tentang Pedoman Pengelolaan Barang Milik Daerah

Pemerintah Provinsi Jawa Tengah. 2008. Peraturan Daerah Provinsi Jawa Tengah No 5 /2017 tentang Pengelolaan Barang Milik Daerah

Informasi dari Internet:

Sahid Sutomo, 2013, Strategi Pengelolaan Aset,http://sahidsutomo.blogspot.com/201 3/10/strategi-pengelolaan-aset.html 